\title{
Wnt Signaling, Stem Cells, and Cancer of the Gastrointestinal Tract
}

\author{
Arnout Schepers and Hans Clevers \\ Hubrecht Institute, KNAW and University Medical Centre Utrecht, 3584CT Utrecht, The Netherlands \\ Correspondence: h.clevers@hubrecht.eu
}

The Wnt signaling pathway was originally uncovered as one of the prototype developmental signaling cascades in invertebrates as well as in vertebrates. The first indication that Wnt signaling also plays a role in the adult animal came from the study of the intestine of Tcf-4 ( $T C f 7 L 2)$ knockout mice. The gastrointestinal epithelium continuously self-renews over the lifetime of an organism and is, in fact, the most rapidly self-renewing tissue of the mammalian body. Recent studies indicate that Wnt signaling plays a central role in the biology of gastrointestinal stem cells. Furthermore, mutational activation of the Wnt cascade is the principle cause of colon cancer.

$T^{\mathrm{h}}$ he human stomach consists of the corpus and the pyloric antrum (Fig. 1A), segments with discrete functional properties (Karam 1999). Hydrochloric acid and zymogens are secreted in the corpus, whereas cells in the pyloric antrum mainly secrete mucus and gastric hormones. Like the intestine, the gastric epithelium has a glandular structure and is constantly renewed by progeny of stem cells. Tubular-shaped mucosal invaginations called gastric units consist of a pit and gland region, where the gland can be further subdivided into the isthmus, neck, and base. Each pit branches into a number of glands. The composition of the gastric units differs between the corpus and the pyloric antrum. The corpus has short pits and long glands (Fig. 1D), which contain a variety of surface mucous cells, parietal cells secreting acid and intrinsic factor, chief cells with zymogen granules, and hormone- secreting endocrine cells (Karam and Leblond 1992). Glands of the pyloric antrum are short and feed into a long pit (Fig. 1C). Pyloric units mainly consist of mucous cells, enteroendocrine cells, and occasional acid-secreting cells (Lee and Leblond 1985). In the corpus, mucus-secreting cells migrate from the gland to the surface epithelium, where they live for $\sim 3$ days. Parietal cells live for $\sim 2$ months and migrate bidirectionally toward the surface and the base of the gland. Chief cells migrate to the base of the gland and live for $\sim 6$ months (Karam 1993; Karam and Leblond 1993a,b).

There is one major difference between the human and mouse stomach, i.e., the presence of a forestomach in the latter. The rodent forestomach epithelium resembles that of the esophagus or the epidermis of the skin, i.e., it is a keratinizing stratified epithelium.

Editors: Roel Nusse, Xi He, and Renee van Amerongen

Additional Perspectives on Wnt Signaling available at www.cshperspectives.org

Copyright (C) 2012 Cold Spring Harbor Laboratory Press; all rights reserved; doi: 10.1101/cshperspect.a007989

Cite this article as Cold Spring Harb Perspect Biol 2012;4:a007989 
A. Schepers and H. Clevers

A

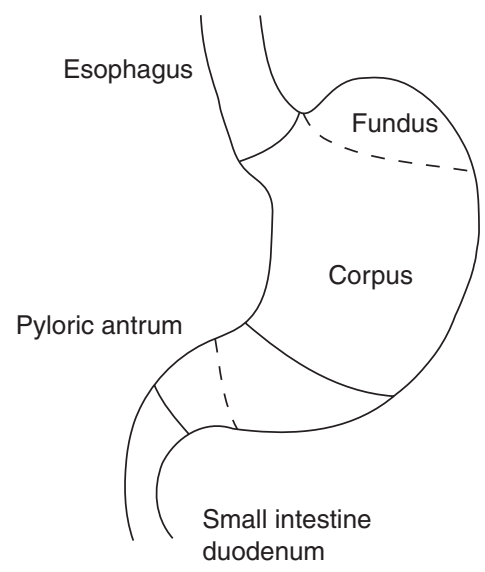

C

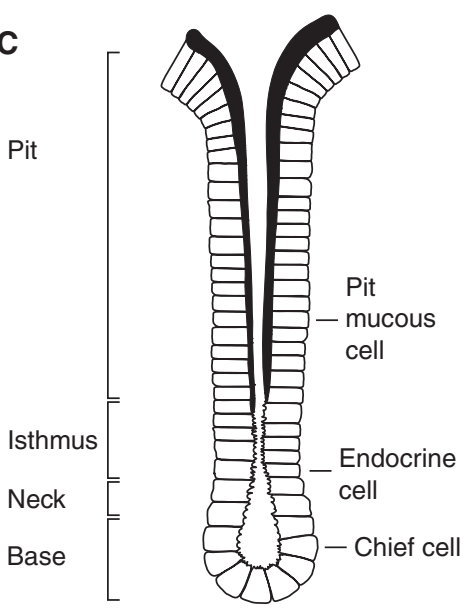

B

Mouse stomach

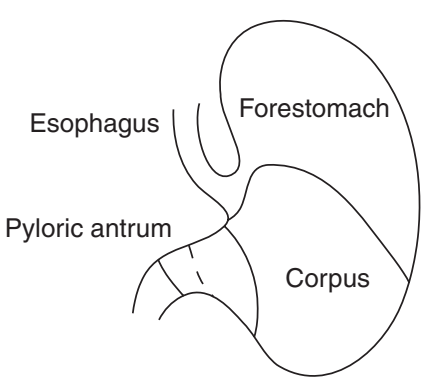

D

Pit

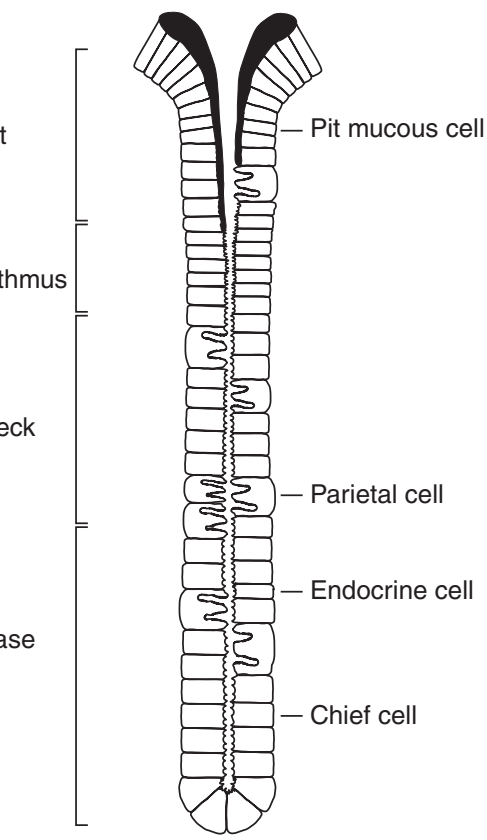

Figure 1. Anatomy of the human and mouse stomach. (A) Human stomach. (B) Mouse stomach. (C) Gastric unit of the pyloric antrum. (D) Gastric unit of the corpus.

\section{THE INTESTINE}

The intestinal wall consists of three main layers. The outer layer contains smooth muscle cells responsible for peristaltic movement of the stool toward the anus (Leedham et al. 2005). The middle layer of connective tissue, the stroma, holds many nerves and lymphatic vessels, whereas the inner layer is made up of a simple epithelium, i.e., a one-cell-layer epithelial sheet. Anatomically and functionally, the intestinal tract consists of the small intestine (duodenum, jejunum, and ileum) and the colon. The small intestine is mainly dedicated to nutrient absorption, whereas the colon mainly functions to resorb water. This functional difference is reflected by the structure and composition of the epithelium. The small intestinal epithelium is organized in a glandular structure with crypts and fingerlike structures called villi that maximize the exchange surface. Villi are composed of a mixture of differentiated cells: absorptive enterocytes, mucus-secreting goblet cells, hormone-producing enteroendocrine 
cells, secretory tuft cells (Gerbe et al. 2011), and cup cells with unknown function (Madara 1982). The colon contains crypts, but has a flat surface epithelium rather than villi. In accordance with their function, absorptive enterocytes are most abundant in the proximal small intestine, whereas mucus-secreting goblet cells are most abundant in the distal part of the small intestine and colon, reflecting the need for lubrication after water resorption from the stool. All epithelial cells derive from progenitor cells in the proliferative crypts. A mouse intestine contains about a million crypts, each of which generates approximately 300 new cells per crypt per day (Hagemann et al. 1970). The driving force behind this renewal are the intestinal stem cells that are located at the crypt base and divide on average once per day (Potten et al. 1990; Barker et al. 2007). They give rise to a pool of transitamplifying cells that divide every $12-16 \mathrm{~h}$, gradually migrate upward, and differentiate to fuel the villi with mature functional cells. Being pushed up by the newly generated cells, these cells keep migrating to the tops of the villi, where they eventually undergo apoptosis and are shed into the lumen. Paneth cells of the small intestine do not follow this migration pattern. They remain at the bottom of the crypt where they reside for $6-8$ weeks and classically are believed to regulate the local microbial environment by secreting antimicrobial peptides and lysozyme (Bjerknes and Cheng 1981a,b; Ireland et al. 2005).

\section{Wnt SIGNALING CONSTITUTES THE MAJOR DRIVING FORCE BEHIND HOMEOSTATIC SELF-RENEWAL OF THE CRYPT}

The Wnt signaling pathway was originally uncovered as one of the prototype developmental signaling cascades in invertebrates as well as vertebrates (Cadigan and Nusse 1997). The first indication that Wnt signaling also plays a role in the adult came from the study of Tcf-4 (Tcf7L2) knockout mice (Korinek et al. 1998). At birth, Tcf $7 \mathrm{~L} 2^{-/-}$mice lack proliferative stem cells in the prospective crypt regions ("intervillus pockets") between villi. Subsequent studies documented similar roles for Wnt signaling in other adult stem cell compartments, such as the skin and bone marrow (Reya and Clevers 2005). Later it was shown that loss of Wnt signaling by genetic deletion of $\beta$-catenin (Fevr et al. 2007) or through inhibition of Wnt receptors by recombinant Dkk1 (Pinto et al. 2003; Kuhnert et al. 2004) resulted in complete ablation of intestinal crypts in the adult mouse. A complete inventory of the expression of Wnt receptors and ligands in the murine intestine is given in (Gregorieff et al. 2005).

Wnt signals affect cell-fate determination in the small intestine. In addition to proliferative defects, Tcf7L2 ${ }^{-/-}$mice lack enteroendocrine cells (Korinek et al. 1998), whereas inhibition of Wnt by Dkk1 results in loss of secretory lineages (Pinto et al. 2003). A more recent study found that Wnt is necessary for the development of early secretory progenitors, but not required for the differentiation and maturation of enteroendocrine precursors (Wang et al. 2007). Paneth cells at the base of the crypt receive abundant Wnt signals, have high levels of nuclear $\beta$-catenin, but do not proliferate. Rather, these postmitotic cells use Wnt signals for their terminal differentiation (Andreu et al. 2005; van Es et al. 2005). This is at least in part mediated through the Wnt target gene Sox9. Conditional knockout of this transcription factor resulted in a loss of Paneth cells, increased cell proliferation in the crypts, and an increased number of cells expressing c-Myc (Bastide et al. 2007; MoriAkiyama et al. 2007).

Nuclear $\beta$-catenin is highest in cells at the base of the crypt, implying that a Wnt gradient exists along the crypt axis (Kongkanuntn et al. 1999; van de Wetering et al. 2002). Indeed, geneexpression analysis of horizontally dissected human colon samples showed the highest expression of the Wnt target program in the base of the crypts and a gradual decrease toward the top (Kosinski et al. 2007). The Wnt gradient is believed to control the spatial organization of the epithelium. For example, EphB2 and B3, wellknown sorting receptors, are Wnt target genes. Their expression follows the Wnt gradient, i.e., they are highest at the crypt bottom. Their ligands, e.g., EphrinB1, are expressed in an opposite fashion, i.e., highest on the villi. Repulsive forces between EphB receptors and Ephrin 
ligands position cells along the crypt-villus axis. This is particularly evident for Paneth cells that uniquely express EphB3. In EphB3 mutant mice, Paneth cells do not occupy the crypt bottom but are scattered along the crypt-villus axis (Batlle et al. 2002).

\section{ACTIVATING MUTATIONS IN THE WNT PATHWAY CAUSE INTESTINAL CANCER}

Abnormal Wnt signaling has been associated with cancer in many tissues (Reya and Clevers 2005). In the majority of sporadic colorectal cancers the adenomatous polyposis coli (APC) gene is mutated (Kinzler and Vogelstein 1996). Colorectal cancers without APC mutations often have Axin2 mutations (Liu et al. 2000) or activating point mutations in the destruction motif of $\beta$-catenin (Morin et al. 1997). The APC gene was identified to be mutated in familial adenomatous polyposis (FAP) patients (Kinzler et al. 1991; Nishisho et al. 1991). These patients have one defective APC allele and develop colon polyps by loss of heterozygosity (LOH). Polyps are benign but may progress into malignant adenocarcinoma over time by sustaining additional mutations. Loss of APC leads to inappropriate stabilization of $\beta$-catenin (Rubinfeld et al. 1996; Korinek et al. 1997). Overactive Wnt signaling is one of the key events in polyp initiation (Oshima et al. 1997), but additional mutations are required to progress into adenocarcinoma. Later stages of tumor progression mainly depend on activation of RAS or inactivation of P53, SMAD4, and PTEN (Fearon and Vogelstein 1990; Janssen et al. 2006; Marsh et al. 2008; Luo et al. 2009).

Several mouse models exist for FAP. Of note, mice develop polyps predominantly in the small intestine, whereas FAP patients mainly have polyps in the colon. The first mouse model for FAP (multiple intestinal neoplasia or min) was isolated after random mutagenesis (Moser et al. 1990). These mice harbor a mutation in the $A p c$ gene; therefore the strain was called $A p c^{\text {min }}$ ( $\mathrm{Su}$ et al. 1992). Since then, several Apc mutations have been generated by gene-targeting techniques, e.g., $A p c^{\Delta 716}, A p c^{\Delta 1638}$, and the hypomorphic alleles $A p c^{n e o R}$ and $A p c^{n e o F}$ (Fodde et al.
1994; Oshima et al. 1995; Li et al.). These mice all develop adenomas after $\mathrm{LOH}$, but polyp numbers and the location of eventual tumors are different. Conditional deletion of both copies of a conditional floxed $A p c$ allele in adult animals converted the entire epithelium into "crypt-progenitor-like" cells within days (Sansom et al. 2004), a phenomenon dependent on an intact $c M y c$ allele (Sansom et al. 2007). In mice with truncated Apc proteins, $\beta$-catenin/ T-cell factor (TCF) transcriptional activity inversely correlated with Apc levels. The extent of Wnt activation turned out to be the major factor determining the number of polyps.

Analysis of $\mathrm{LOH}$ and point mutations in adenomas from colorectal cancer patients provided insight in the diversity of APC mutations (Albuquerque et al. 2002). The APC protein has seven 20-amino-acid repeats that are involved in the down-regulation of $\beta$-catenin. The analysis showed that there is selection for APC genotypes that have one or two repeats left. Based on these findings it was proposed that there is a level of Wnt activity which is "just right" for tumor formation. Such a quantitative nature of Wnt signaling was also described in embryonic development (Kielman et al. 2002).

From these studies, it was suggested that benign transformation of APC-mutant epithelial cells involves the constitutive expression of a genetic program that is normally involved in self-renewal of crypt (stem) cells. Initial studies pointed to cMyc and CyclinD1 as pivotal players in the transforming Wnt target gene program in colorectal cancer (He et al. 1998; Tetsu and McCormick 1999). When microarraying became available, the "global" genetic program that is controlled by $\beta$-catenin/TCF in colorectal cancer cells was indeed found to resemble the genetic program of the proliferative compartment of the intestinal crypt (van de Wetering et al. 2002; Sabates-Bellver et al. 2007; van der Flier et al. 2007).

\section{INTESTINAL STEM CELLS}

The existence of a self-renewing, multipotent stem cell population in adult crypts was first shown by tracking randomly introduced, somatic 
mutations (Winton and Ponder 1990; Bjerknes and Cheng 2002). Clones of cells marked by these sporadic mutations were long-lived and contained all of the different epithelial cell lineages, indicating a common progenitor. Tracking of spontaneous mitochondrial mutations revealed the presence of multiple multipotent cells in adult crypts (Taylor et al. 2003). Today, it is generally accepted that stem cells reside at the base of the crypt; however, there has been much debate about the exact location of the stem cells. Cells located at the so-called +4 position between the Paneth cells and the transitamplifying cells were first claimed to be the stem cells. Support for the +4 cell came from studies based on radiosensitivity and label retention of these cells (Potten et al. 1974). Several markers, including Bmil, mTert, and Hopx, have been proposed to mark the +4 cell (Sangiorgi and Capecchi 2008; Montgomery et al. 2011; Takeda et al. 2011). Small cycling cells intermingled between the Paneth cells, so-called crypt base columnar (CBC) cells, were proposed as alternative stem cells (Cheng and Leblond 1974). Later marking studies also hinted at the CBC cells as being the stem cells (Bjerknes and Cheng 1999, 2002).

By definition, a stem cell can renew itself and give rise to all the specialized progeny within a given tissue. Two approaches can test this: transplantation of sorted, candidate stem cells into recipient animals, or lineage tracing by genetic marking. The latter approach has been successfully used in identifying Wnt-dependent stem cells in the intestinal tract. To perform lineage tracing, a candidate gene must be identified that—on its own — marks a putative stem cell. By transgenesis or gene-targeting technology, mice can be generated that express an inducible recombinase such as the tamoxifeninducible CreERT2 (Hayashi and McMahon 2002) under the control of the regulatory elements of the candidate gene.

The first study addressing the existence of intestinal stem cells by lineage tracing used the gene encoding the leucine-rich repeat containing G-protein receptor Lgr5 (Gpr49). The global elucidation of the Wnt-driven genomic program was key to the identification of Lgr5 and the subsequent confirmation of CBC cells being ISCs (van de Wetering et al. 2002; Barker et al. 2007). Because Wnt is the driving force behind proliferation in the crypt, multiple individual Wnt target genes were analyzed to identify potential stem cell-specific genes. Whereas most target genes were expressed throughout the crypt, a small set of genes had a more restricted expression (van der Flier et al. 2007). One of these genes, Lgr5, was exclusively expressed in the small cycling $\mathrm{CBC}$ cells. With the first molecular marker for $\mathrm{CBC}$ cells in hand, several studies were performed to test the stem cell potential of these cells. First, a LacZ ( $\left.\operatorname{Lgr} 5^{\mathrm{LacZ}}\right)$ and an enhanced green fluorescent protein (EGFP) (Lgr5 ${ }^{\text {EGFP-IRES-CreERT2 }}$; IRES, internal ribosome entry site) knockin were generated to confirm Lgr5 expression in the CBC cells. Then, Lgr $5^{\text {EGFP-IRES-CreERT2 }}$ mice were crossed with a cAMP response element (CRE) -activatable Rosa2 $6^{\text {LacZ }}$ reporter mouse strain to be able to mark Lgr5-positive cells and follow their offspring (Fig. 2A-C). Lgr5-positive cells were shown to generate all different cell types (Fig. $2 \mathrm{D}, \mathrm{E})$ of the intestinal epithelium for the lifetime of the mouse. The tracings confirmed the CBC stem cell zone model originally proposed by Bjerknes and Cheng (1981c). Sorting and gene-expression analysis of Lgr5-EGFP cells revealed that these stem cells express several additional Wnt target genes such as Olfm4 and Ascl2 (van der Flier et al. 2009a,b). The transcription factor Ascl2 is of particular interest as it appears to function as the master regulator of the intestinal stem cell (van der Flier et al. 2009b). Culture conditions were subsequently developed that allow the outgrowth of a single small intestinal Lgr5 stem cell to form ever-expanding, self-organizing "miniguts," closely resembling the normal gut epithelium (Sato et al. 2009). This three-dimensional organoid culture system is based on EGF and on Rspondin1, a secreted Wnt agonist previously shown to induce crypt hyperplasia in vivo (Kim et al. 2005). Using this organoid technology it was shown that Paneth cells, which are intermingled with Lgr5 stem cells at crypt bottoms, constitute at least part of the crypt stem cell niche: They produce the essential stem cell growth factors EGF and 


\section{A. Schepers and H. Clevers}

A

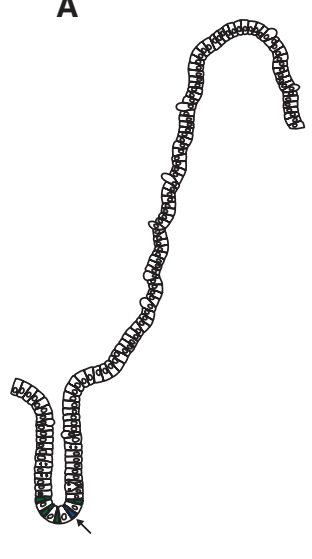

Cre induction (day 0)

$$
\text { D }
$$

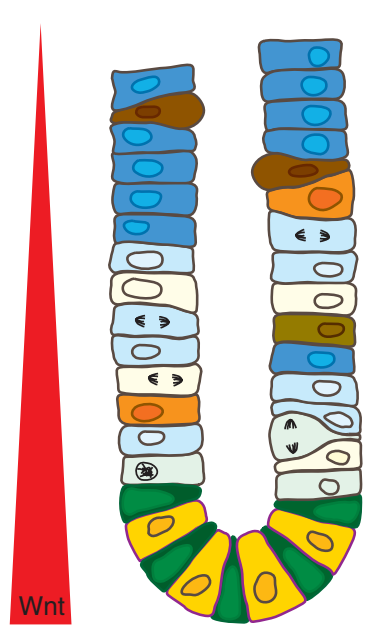

B

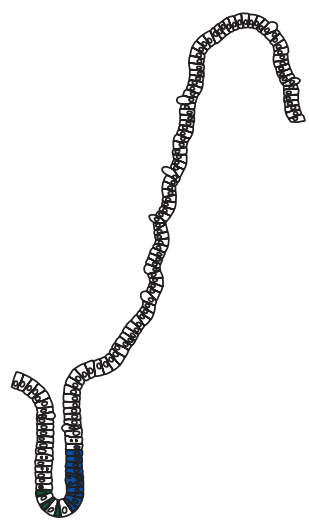

Short-term tracing

( 2 days)

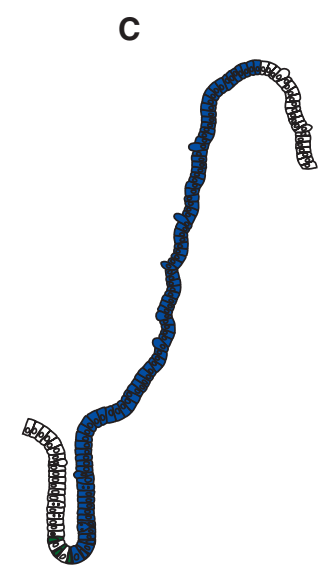

Long-term tracing ( 5 days -2 yr)

E

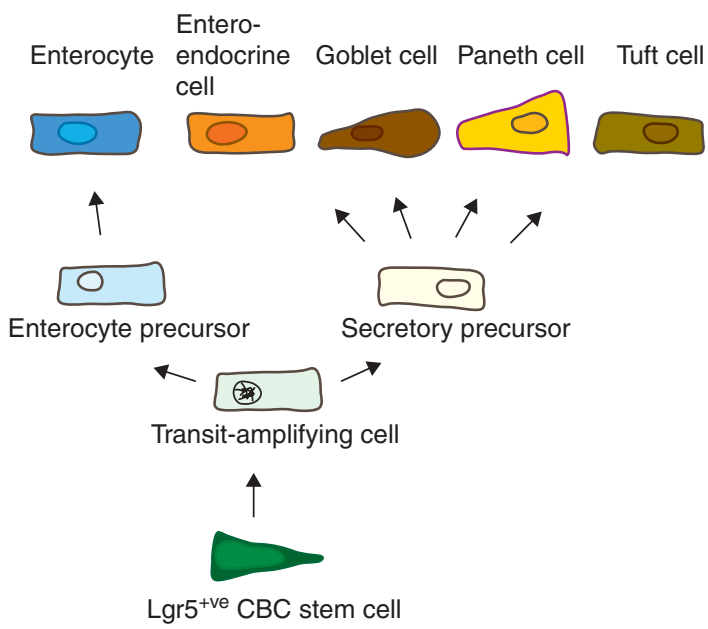

Figure 2. Lgr5-positive CBC cells give rise to all epithelial lineages. (A) Low dose of tamoxifen activates Cre recombinase sporadically in CBC cells. $(B)$ Multiple daughter cells are labeled 2 days after induction. $(C)$ Induced Lgr5-positive cells generate labeled "ribbons" containing all different cell types of the intestinal epithelium for the lifetime of the mouse. $(D)$ Architecture of a small intestinal crypt with the Wnt gradient depicted in red. (E) Schematic overview of the generation of different cell lineages from Lgr $5^{+\mathrm{ve}} \mathrm{CBC}$ stem cells.

Wnt3 and carry the Notch ligands Dll1 and Dll4 (Sato et al. 2011). Recently, it was reported that hepatocyte growth factor, secreted by stromal myofibroblasts, can enhance $\beta$-catenin-dependent transcription and maintain stem cell properties (Vermeulen et al. 2010).

The Lgr5 stem cells display some unexpected characteristics. Lineage tracing of stem cells using a multicolor reporter showed that they divide symmetrically and compete for essential niche signals (i.e., direct contact with Paneth cells) to maintain stemness (Snippert et al. 2010; Sato et al. 2011). ISCs that lose contact with Paneth cells lose stemness and differentiate into transit-amplifying cells. Paneth cell numbers remain constant under normal homeostasis, but it is currently unknown how this is regulated. Lgr5 stem cells are never quiescent: they have 
telomerase activity, which allows them to complete $\sim 1000$ cell divisions in the lifetime of a mouse (Schepers et al. 2011).

Many other potential stem cell markers have been reported, although most are only supported by positional information (reviewed by Barker et al. 2010a). Yet, lineage tracing studies involving CD133 (Zhu et al. 2009) and Sox9 (Furuyama et al. 2011), two genes that mark broader populations in the crypt including CBC cells, have confirmed the Lgr5-based findings. In addition, Bmil (Sangiorgi and Capecchi 2008; Tian et al. 2011) and Hopx (Takeda et al. 2011), both proposed +4 markers, have been used to trace all cell types in the crypt. Interestingly, $\mathrm{Bmil}^{+} / \operatorname{Lgr}^{-}$cells were shown to be able to rescue the intestinal epithelium after deletion of Lgr5 $^{+}$stem cells (Tian et al. 2011). Singlemolecule transcript counting has revealed that Bmil expression is coexpressed in CBC cells at lower crypt positions and is nearly constant throughout the crypt axis (Itzkovitz et al. 2011). Until now the nature of the $\mathrm{Bmil}^{+} / \operatorname{Lgr}^{-}$cells remains unclear.

\section{GASTRIC STEM CELLS}

At birth, gastric units are polyclonal but they become monoclonal during adulthood (Nomura et al. 1998). Gastric self-renewal is driven by gastric stem cells (Thompson et al. 1990) and as in the small intestine there is some discrepancy about the exact location of the stem cells.

In 1948, studies using incorporation of labeled nucleotides suggested that renewal of gastric cells was driven by one or a few cells in the isthmus of both the corpus and the pyloric antrum (Leblond et al. 1948). The first evidence for multipotent stem cells in stomach epithelium came from "inverse tracing" with transgenic Rosa $26^{\text {LacZ }}$ mice. Chemical random mutagenesis resulted in loss of ubiquitous transgene expression at low frequency. LacZ-negative clones were found containing all four gastric cell lineages (Bjerknes and Cheng 2002). This indicated the existence of a multipotent progenitor/stem cell. Clones consisting of only one lineage were still present 48 weeks after mutagenesis, indicating the presence of long-lived monopotent pro- genitors. Because the mutations occurred in random cells, the identity of the stem cell could not be determined. Study of inheritance patterns of random mitochondrial mutations revealed that each gastric unit contains more than one multipotent adult stem cell (McDonald et al. 2008).

These findings position proliferating stem cells in the isthmus, where their direct progeny differentiates and migrates up and down toward the pit and the gland. Although this model is still considered valid for the corpus, new evidence using Lgr5 lineage tracing places multipotent stem cells at the bottom of the gastric units of the pyloric antrum (Barker et al. 2010b). Using the same strategies as for the intestine, it was shown that Lgr5 marks three to four cells at the bottom of pyloric gastric units. No Lgr5 expression was found in the isthmus. Lineage tracing with $\operatorname{Lgr} 5^{\text {EGFP-IRES-CreERT2 }}$ Rosa26 ${ }^{\text {LacZ }}$ mice showed that Lgr5 cells in the stomach are cycling and give rise to all the gastric cell lineages. Examination of the ultrastructure of Lgr 5 cells by electron microscopy showed a large centrally located nucleus, limited basal rough endoplasmic reticulum (ER), apical microvilli, and no secretory granules. Expression profile analysis comparing cells with high Lgr5 expression (Lgr $5^{\text {hi }}$ ) with their assumed daughter cells $\left(\mathrm{Lgr} 5^{\mathrm{lo}}\right)$ showed an enrichment of Wnt target genes. Culture conditions were developed under which the Lgr5 cells were able to form and maintain in vitro gastric organoids. The "ministomachs" were grown under similar conditions as the previously described intestinal organoids (Sato et al. 2009), but had an additional dependence on Wnt3a for growth and required FGF10 for budding into multiunit structures. The gastric organoids expressed Lgr5 and several gastric epithelial markers, however, no pit or enteroendocrine cells were observed. Differentiation toward these cell lineages did occur after reduction of the Wnt3a concentration (Barker et al. 2010b).

Work with a Villin-Cre transgenic mouse has revealed an independent stem cell population: rare progenitor cells at or just below the isthmus and in the base of antral glands (Qiao et al. 2007). These cells were shown to be quiescent under normal homeostatic conditions, 
but were able to divide on stimulation with the cytokine interferon $\gamma$. The reactivation subsequently gave rise to all lineages of antral glands. The fact that all gastric cells, including the quiescent stem cells in isthmus, are derived from Lgr5-positive cells (Barker et al. 2010b) suggests that stem cells may switch between a cycling Lgr5-positive state and a quiescent Lgr5-negative state.

\section{THE CELL OF ORIGIN OF INTESTINAL CANCER}

Tumors are thought to originate from a single cell. Two concepts were proposed for the origin and migration of tumor cells in the intestine: the "top-down" and "bottom-up" models. The initiation of cancer could be caused by reprogramming of early progenitors or even more differentiated cells, which migrate top down. The "late progenitor" cell of origin of cancer was suggested based on the presence of dysplastic cells at the luminal surface that carried mutations in Apc, whereas crypt cells were normal (Shih et al. 2001). Owing to the rapid turnover of the intestine, a mutated transit-amplifying or villus cell would have little time to form a tumor. However, positional cues like the expression of EphB2 are lost in many adenocarcinomas (Batlle et al. 2005), and it has been shown that mutations in Apc can block progression along the crypt-villus axis (Sansom et al. 2004). It was shown that cancer can originate from mutations in short-lived progenitors, but that this happens very infrequently and such adenomas develop slowly (Barker et al. 2009).

The bottom-up model defines stem cells as the cell of origin. Apc deletion in Lgr5+, CD133+, or Bmil + cells in the base of the crypt indeed resulted in efficient and fast generation of adenomas (Sangiorgi and Capecchi 2008; Barker et al. 2009; Zhu et al. 2009). The notion that stem cells may play a role in carcinogenesis is supported by the properties attributed to stem cells and cancer (initiating) cells. Both are thought to be able to self-renew and give rise to more differentiated daughters, have active telomerase, and be resistant to apoptosis (Wicha et al. 2006).
Within established adenomas or colorectal carcinomas, cells may reside that display stem cell-like properties, so-called cancer stem cells (CSCs). Several markers have been used to isolate potential CSCs and test their tumorigenic potential in xenograft assays (Dalerba et al. 2007; O'Brien et al. 2007; Ricci-Vitiani et al. 2007). Cells sorted based on CD133 or a combination of epithelial cell adhesion molecule (EpCAM) and CD44 were able to reproduce tumors in immunodeficient mice on serial transplantation. Interestingly, CD133 and CD44 are also expressed in the proliferative compartment of crypts (Zeilstra et al. 2008; Snippert et al. 2009). Genetic profiling of Ephb2 + and Lgr5+ expressing cells in the crypt revealed a gene signature specific for ISCs (Barker et al. 2007; Jung et al. 2011). A large part of the ISC-specific program was overexpressed in colorectal cancer samples. Furthermore, the ISC program was enriched in aggressive, poorly differentiated colorectal cancers compared to more benign welldifferentiated cancers. Although proliferative genes were enriched in all tumor cells, ISC-specific genes marked only a subset of tumor cells (Jung et al. 2011). Heterogeneity in tumors is also reflected by the fact that not all tumor cells have high nuclear $\beta$-catenin (Fodde and Brabletz 2007). Mainly cells migrating into neighboring stromal tissues and cells located at the invasive front show high nuclear $\beta$-catenin staining. Because the tumors were derived from Apc-deficient cells with constitutively high Wnt signaling, Apc-independent $\beta$-catenin down-regulating mechanisms may be present within tumors.

Cells with the highest Wnt activity were found to define the colon CSCs (Vermeulen et al. 2010). In addition, it was shown that certain CSC properties can be gained or lost depending on the microenvironment. High Wnt activity was preferentially found in cells close to myofibroblasts in xenografts, and coculture of colorectal cancers with colon myofibroblasts or addition of conditioned medium from these cells markedly increased clonogenicity. These results suggest that stemness of colorectal cancer cells is a dynamic process that can be influenced by external factors. Genetic instability in tumors can further modify CSCs and make it 
difficult to find markers of a targetable pool of cells with stem cell potential (Fodde et al. 2001; Soreide et al. 2006; Odoux et al. 2008).

Mutations in APC, Axin, and $\beta$-catenin are also present in gastric cancer (Ebert et al. 2002; Ushijima and Sasako 2004; Pan et al. 2008). Gastric cancer patients show accumulation of nuclear $\beta$-catenin and abnormal methylation of Wnt pathway genes (Nakatsuru et al. 1992; Park et al. 1999; Clements et al. 2002). Apc min mice develop tumors in the stomach (Tomita et al. 2007) and APC germline mutations in humans give a 10 times higher risk of gastric cancer (Offerhaus et al. 1992). High Wnt signaling cooperates with inflammatory signaling pathways to contribute to gastric tumor development (Oshima et al. 2006). For example, Helicobacter infection would lead to tumor necrosis factor- $\alpha$ (TNF- $\alpha$ ) expression in macrophages, which in turn stimulates surrounding cells to promote Wnt signaling (Oguma et al. 2008). Apc deletion in Lgr5 + cells in the stomach leads to efficient tumor formation, suggesting gastric stem cells to be the cells of origin of gastric cancer (Barker et al. 2010b).

\section{Lgr RECEPTORS MEDIATE R-SPONDIN SIGNALING}

The fact that Lgr5 marks stem cells in multiple tissues (Barker et al. 2010a) raises interest in its function. The study of the role of the Lgr5 receptor has been complicated by the lack of a known natural ligand. Lgr5 belongs to a family of serpentine receptors that are defined by the presence of a large extracellular, ligand-binding domain. Lgr1, -2 , and -3 represent the G-protein-coupled receptors for the hormones luteinizing hormone (LH), follicle-stimulating factor (FSH), and thyroid-stimulating hormone (TSH). Lgr7 and -8 are receptors for insulinlike molecules such as Relaxin (reviewed by Barker and Clevers 2010). Lgr4, -5 , and -6 comprise a subfamily within this group of receptors. The proposed fly ortholog of this subfamily, dLgr2, is the receptor for Bursicon (Baker and Truman 2002). Because the two cysteine-knot-containing subunits of Bursicon are orthologous to vertebrate bone morphogenetic protein antago- nists, it was long thought that the ligand for the mammalian Lgr4/5/6 receptors could be found within this family of secreted molecules.

Lgr5 null mice die within 1 day after birth owing to defects caused by fusion of the tongue to the floor of the mouth (Morita et al. 2004). It has been reported that Lgr5 null neonatal mice show premature Paneth cell differentiation (Garcia et al. 2009). However, conditional deletion of Lgr5 in the intestine does not result in a clear crypt phenotype (de Lau et al. 2011). In the intestinal crypt, Lgr5 is coexpressed with Lgr4, which has a broader expression pattern throughout the proliferative compartment. Conditional deletion of Lgr4 results in loss of proliferating cells in the crypt and eventual disappearance of many crypts (de Lau et al. 2011). Additional deletion of Lgr5 enhances this phenotype. Microarrying revealed the loss of a Wnt target gene program, implying that Lgr4 and Lgr5 act agonistically in the Wnt pathway. In a separate study of a hypomorphic Lgr4 mutant mouse, crypt proliferation was moderately affected, but intestinal organoids could not be grown unless the Wnt pathway was activated by the GSK3-inhibitor lithium (Mustata et al. 2011).

R-spondins are small secreted proteins that have been associated with $\beta$-catenin signaling previously. Yet, there has not been a consensus on their mechanism of action. Functionally, R-spondins were shown to activate $\beta$-catenin signaling (Kazanskaya et al. 2004, 2008; Kim et al. 2005) and transgenic overexpression of R-spondin1 or injection of recombinant Rspondin protein results in dramatic crypt expansion (Kim et al. 2005). In disease models, $\mathrm{R}$-spondin 1 accelerates regeneration of the intestine after irradiation (Bhanja et al. 2009; Takashima et al. 2011). Reduction of R-spondin 2 protein did not affect lithium-induced $\beta$-catenin activity in Xenopus (Kazanskaya et al. 2004), indicating that R-spondin functions upstream of the destruction complex.

Two independent studies have shown that all four R-spondin proteins can bind to the leucine-rich domains of Lgr4, Lgr5, and Lgr6 (Carmon et al. 2011; de Lau et al. 2011). Moreover, de Lau et al. (2011) found that the Lgr proteins 

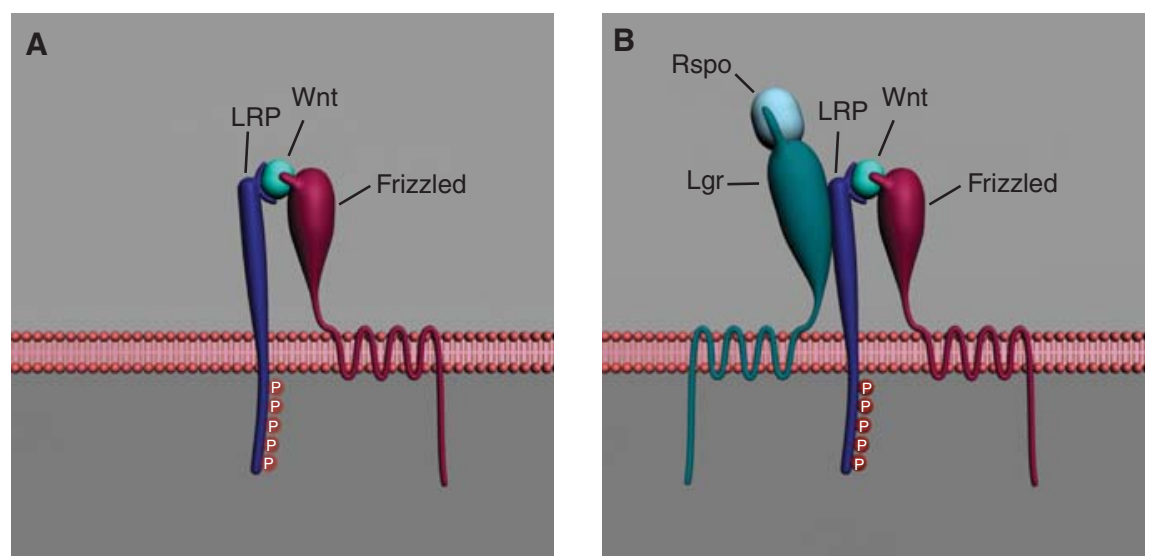

Figure 3. Schematic representation of the Wnt signaling complex. (A) The classical complex comprised of Wnt, Frizzled, and low-density lipoprotein receptor-related protein (LRP). (B) New proposed model including the Lgr receptor and R-spondin.

reside as facultative components within Frizzled/Lrp5-6 complexes. Removal of endogenous Lgr4 was found to abolish the enhancing effect of R-spondin1 but did not inhibit the stimulating effect of Wnt3a (Carmon et al. 2011; de Lau et al. 2011). Furthermore, the enhancing effect could be rescued with an Lgr5 construct with a mutated "DRY" domain (de Lau et al. 2011), which is supposed to be essential for G-protein coupling (Flanagan 2005). Carmon et al. (2011) also reported that G-protein signaling was not activated on Lgr5 engagement by R-spondin 1 .

Taken together, the Lgr5-related stem cell markers act as receptors for R-spondins. On R-spondin/Lgr5 interaction, the association of Lgr5 with the Frizzled complex subsequently allows the activating signal to be funneled into the canonical Wnt cascade (Fig. 3). The identification of the Lgr proteins as receptors for the R-spondin Wnt agonists fortifies the tight link between Wnt signaling and adult stem cell biology. The R-spondin proteins as well as the Lgr5 subfamily of receptors appear to be a vertebrate invention. The system functions to augment localized Wnt signals. Thus, these molecules allow expansion of small localized Wnt-driven stem cell niches into larger structures that include transit-amplifying compartments. This vertebrate adaptation of the Wnt pathway may have allowed the appearance of large body sizes within the animal kingdom.

\section{ACKNOWLEDGMENTS}

We thank members of the laboratory for critically reading the manuscript, and M. Isselman for the Wnt complex illustrations.

\section{REFERENCES}

Albuquerque C, Breukel C, van der Luijt R, Fidalgo P, Lage P, Slors FJ, Leitao CN, Fodde R, Smits R. 2002. The “justright" signaling model: APC somatic mutations are selected based on a specific level of activation of the $\beta$ catenin signaling cascade. Hum Mol Genet 11: 15491560.

Andreu P, Colnot S, Godard C, Gad S, Chafey P, Niwa-Kawakita M, Laurent-Puig P, Kahn A, Robine S, Perret C, et al. 2005. Crypt-restricted proliferation and commitment to the Paneth cell lineage following Apc loss in the mouse intestine. Development 132: 1443-1451.

Baker JD, Truman JW. 2002. Mutations in the Drosophila glycoprotein hormone receptor, rickets, eliminate neuropeptide-induced tanning and selectively block a stereotyped behavioral program. J Exp Biol 205: 2555-2565.

Barker N, Clevers H. 2010. Leucine-rich repeat-containing G-protein-coupled receptors as markers of adult stem cells. Gastroenterology 138: 1681-1696.

Barker N, van Es JH, Kuipers J, Kujala P, van den Born M, Cozijnsen M, Haegebarth A, Korving J, Begthel H, Peters PJ, et al. 2007. Identification of stem cells in small intestine and colon by marker gene Lgr5. Nature 449: 10031007. 
Barker N, Ridgway RA, van Es JH, van de Wetering M, Begthel H, van den Born M, Danenberg E, Clarke AR, Sansom OJ, Clevers H. 2009. Crypt stem cells as the cellsof-origin of intestinal cancer. Nature 457: 608-611.

Barker N, Bartfeld S, Clevers H. 2010a. Tissue-resident adult stem cell populations of rapidly self-renewing organs. Cell Stem Cell 7: 656-670.

Barker N, Huch M, Kujala P, van de Wetering M, Snippert HJ, van Es JH, Sato T, Stange DE, Begthel H, van den Born M, et al. 2010b. $\operatorname{Lgr} 5^{(+\mathrm{ve})}$ stem cells drive self-renewal in the stomach and build long-lived gastric units in vitro. Cell Stem Cell 6: 25-36.

Bastide P, Darido C, Pannequin J, Kist R, Robine S, MartyDouble C, Bibeau F, Scherer G, Joubert D, Hollande F, et al. 2007. Sox9 regulates cell proliferation and is required for Paneth cell differentiation in the intestinal epithelium. J Cell Biol 178: 635-648.

Batlle E, Henderson JT, Beghtel H, van den Born MM, Sancho E, Huls G, Meeldijk J, Robertson J, van de Wetering M, Pawson T, et al. 2002. $\beta$-Catenin and TCF mediate cell positioning in the intestinal epithelium by controlling the expression of EphB/ephrinB. Cell 111: 251-263.

Batlle E, Bacani J, Begthel H, Jonkheer S, Gregorieff A, van de Born M, Malats N, Sancho E, Boon E, Pawson T, et al. 2005. EphB receptor activity suppresses colorectal cancer progression. Nature 435: 1126-1130.

Bhanja P, Saha S, Kabarriti R, Liu L, Roy-Chowdhury N, Roy-Chowdhury J, Sellers RS, Alfieri AA, Guha C. 2009. Protective role of R-spondin1, an intestinal stem cell growth factor, against radiation-induced gastrointestinal syndrome in mice. PLoS ONE 4: e8014.

Bjerknes M, Cheng H. 1981a. The stem-cell zone of the small intestinal epithelium. I. Evidence from paneth cells in the adult mouse. Am J Anat 160: 51-63.

Bjerknes M, Cheng H. 1981b. The stem-cell zone of the small intestinal epithelium. II. Evidence from paneth cells in the newborn mouse. Am J Anat 160: 65-75.

Bjerknes M, Cheng H. 1981c. The stem-cell zone of the small intestinal epithelium. III. Evidence from columnar, enteroendocrine, and mucous cells in the adult mouse. Am J Anat 160: 77-91.

Bjerknes M, Cheng H. 1999. Clonal analysis of mouse intestinal epithelial progenitors. Gastroenterology 116: $7-14$.

Bjerknes M, Cheng H. 2002. Multipotential stem cells in adult mouse gastric epithelium. Am J Physiol Gastrointest Liver Physiol 283: G767-G777.

Cadigan KM, Nusse R. 1997. Wnt signaling: A common theme in animal development. Genes Dev 11: 32863305.

Carmon KS, Gong X, Lin Q, Thomas A, Liu Q. 2011. Rspondins function as ligands of the orphan receptors LGR4 and LGR5 to regulate Wnt/ $\beta$-catenin signaling. Proc Natl Acad Sci 108: 11452-11457.

Cheng H, Leblond CP. 1974. Origin, differentiation and renewal of the four main epithelial cell types in the mouse small intestine. V. Unitarian theory of the origin of the four epithelial cell types. Am J Anat 141: 537-561.

Clements WM, Wang J, Sarnaik A, Kim OJ, MacDonald J, Fenoglio-Preiser C, Groden J, Lowy AM. 2002. $\beta$-Catenin mutation is a frequent cause of Wnt pathway activation in gastric cancer. Cancer Res 62: 3503-3506.

Dalerba P, Dylla SJ, Park IK, Liu R, Wang X, Cho RW, Hoey T, Gurney A, Huang EH, Simeone DM, et al. 2007. Phenotypic characterization of human colorectal cancer stem cells. Proc Natl Acad Sci 104: 10158-10163.

De Lau W, Barker N, Low TY, Koo BK, Li VS, Teunissen H, Kujala P, Haegebarth A, Peters PJ, van de Wetering M, et al. 2011. Lgr5 homologues associate with Wnt receptors and mediate R-spondin signalling. Nature 476: 293-297.

Ebert MP, Fei G, Kahmann S, Muller O, Yu J, Sung JJ, Malfertheiner P. 2002. Increased $\beta$-catenin mRNA levels and mutational alterations of the APC and $\beta$-catenin gene are present in intestinal-type gastric cancer. Carcinogenesis 23: $87-91$.

Fearon ER, Vogelstein B. 1990. A genetic model for colorectal tumorigenesis. Cell 61: 759-767.

Fevr T, Robine S, Louvard D, Huelsken J. 2007. Wnt $/ \beta$ catenin is essential for intestinal homeostasis and maintenance of intestinal stem cells. Mol Cell Biol 27: $7551-$ 7559.

Flanagan CA. 2005. A GPCR that is not "DRY." Mol Pharmacol 68: $1-3$.

Fodde R, Brabletz T. 2007. Wnt/ $\beta$-catenin signaling in cancer stemness and malignant behavior. Curr Opin Cell Biol 19: $150-158$.

Fodde R, Edelmann W, Yang K, van Leeuwen C, Carlson C, Renault B, Breukel C, Alt E, Lipkin M, Khan PM, et al. 1994. A targeted chain-termination mutation in the mouse Apc gene results in multiple intestinal tumors. Proc Natl Acad Sci 91: 8969-8973.

Fodde R, Kuipers J, Rosenberg C, Smits R, Kielman M, Gaspar C, van Es JH, Breukel C, Wiegant J, Giles RH, et al. 2001. Mutations in the APC tumour suppressor gene cause chromosomal instability. Nat Cell Biol 3: 433-438.

Furuyama K, Kawaguchi Y, Akiyama H, Horiguchi M, Kodama S, Kuhara T, Hosokawa S, Elbahrawy A, Soeda T, Koizumi M, et al. 2011. Continuous cell supply from a Sox9-expressing progenitor zone in adult liver, exocrine pancreas and intestine. Nat Genet 43: 34-41.

Garcia MI, Ghiani M, Lefort A, Libert F, Strollo S, Vassart G. 2009. LGR5 deficiency deregulates Wnt signaling and leads to precocious Paneth cell differentiation in the fetal intestine. Dev Biol 331: 58-67.

Gerbe F, van Es JH, Makrini L, Brulin B, Mellitzer G, Robine S, Romagnolo B, Shroyer NF, Bourgaux JF, Pignodel C, et al. 2011. Distinct ATOH1 and Neurog3 requirements define tuft cells as a new secretory cell type in the intestinal epithelium. J Cell Biol 192: 767-780.

Gregorieff A, Pinto D, Begthel H, Destree O, Kielman M, Clevers H. 2005. Expression pattern of Wnt signaling components in the adult intestine. Gastroenterology 129: 626-638.

Hagemann RF, Sigdestad CP, Lesher S. 1970. A quantitative description of the intestinal epithelium of the mouse. $A m$ J Anat 129: 41-51.

Hayashi S, McMahon AP. 2002. Efficient recombination in diverse tissues by a tamoxifen-inducible form of Cre: A 
tool for temporally regulated gene activation/inactivation in the mouse. Dev Biol 244: 305-318.

He TC, Sparks AB, Rago C, Hermeking H, Zawel L, da Costa LT, Morin PJ, Vogelstein B, Kinzler KW. 1998. Identification of c-MYC as a target of the APC pathway. Science 281: $1509-1512$.

Ireland H, Houghton C, Howard L, Winton DJ. 2005. Cellular inheritance of a Cre-activated reporter gene to determine Paneth cell longevity in the murine small intestine. Dev Dyn 233: 1332-1336.

Itzkovitz S, Lyubimova A, Blat IC, Maynard M, van Es J, Lees J, Jacks T, Clevers H, van Oudenaarden A. 2011. Singlemolecule transcript counting of stem-cell markers in the mouse intestine. Nat Cell Biol 14: 106-114.

Janssen KP, Alberici P, Fsihi H, Gaspar C, Breukel C, Franken P, Rosty C, Abal M, El Marjou F, Smits R, et al. 2006. APC and oncogenic KRAS are synergistic in enhancing Wnt signaling in intestinal tumor formation and progression. Gastroenterology 131: 1096-1109.

Jung P, Sato T, Merlos-Suarez A, Barriga FM, Iglesias M, Rossell D, Auer H, Gallardo M, Blasco MA, Sancho E, et al. 2011. Isolation and in vitro expansion of human colonic stem cells. Nat Med 17: 1225-1227.

Karam SM. 1993. Dynamics of epithelial cells in the corpus of the mouse stomach. IV. Bidirectional migration of parietal cells ending in their gradual degeneration and loss. Anat Rec 236: 314-332.

Karam SM. 1999. Lineage commitment and maturation of epithelial cells in the gut. Front Biosci 4: D286-D298.

Karam SM, Leblond CP. 1992. Identifying and counting epithelial cell types in the "corpus" of the mouse stomach. Anat Rec 232: 231-246.

Karam SM, Leblond CP. 1993a. Dynamics of epithelial cells in the corpus of the mouse stomach. II. Outward migration of pit cells. Anat Rec 236: 280-296.

Karam SM, Leblond CP. 1993b. Dynamics of epithelial cells in the corpus of the mouse stomach. III. Inward migration of neck cells followed by progressive transformation into zymogenic cells. Anat Rec 236: 297-313.

Kazanskaya O, Glinka A, del Barco Barrantes I, Stannek P, Niehrs C, Wu W. 2004. R-Spondin2 is a secreted activator of Wnt $/ \beta$-catenin signaling and is required for Xenopus myogenesis. Dev Cell 7: 525-534.

Kazanskaya O, Ohkawara B, Heroult M, Wu W, Maltry N, Augustin HG, Niehrs C. 2008. The Wnt signaling regulator R-spondin 3 promotes angioblast and vascular development. Development 135: 3655-3664.

Kielman MF, Rindapaa M, Gaspar C, van Poppel N, Breukel C, van Leeuwen S, Taketo MM, Roberts S, Smits R, Fodde R. 2002. Apc modulates embryonic stem-cell differentiation by controlling the dosage of $\beta$-catenin signaling. Nat Genet 32: 594-605.

Kim KA, Kakitani M, Zhao J, Oshima T, Tang T, Binnerts M, Liu Y, Boyle B, Park E, Emtage P, et al. 2005. Mitogenic influence of human R-spondin1 on the intestinal epithelium. Science 309: 1256-1259.

Kinzler KW, Vogelstein B. 1996. Lessons from hereditary colorectal cancer. Cell 87: 159-170.

Kinzler KW, Nilbert MC, Vogelstein B, Bryan TM, Levy DB, Smith KJ, Preisinger AC, Hamilton SR, Hedge P, Markham A, et al. 1991. Identification of a gene located at chromosome $5 \mathrm{q} 21$ that is mutated in colorectal cancers. Science 251: 1366-1370.

Kongkanuntn R, Bubb VJ, Sansom OJ, Wyllie AH, Harrison DJ, Clarke AR. 1999. Dysregulated expression of $\beta$-catenin marks early neoplastic change in Apc mutant mice, but not all lesions arising in Msh2 deficient mice. Oncogene 18: 7219-7225.

Korinek V, Barker N, Morin PJ, van Wichen D, de Weger R, Kinzler KW, Vogelstein B, Clevers H. 1997. Constitutive transcriptional activation by a $\beta$-catenin-Tcf complex in $\mathrm{APC}^{-/-}$colon carcinoma. Science 275: 1784-1787.

Korinek V, Barker N, Moerer P, van Donselaar E, Huls G, Peters PJ, Clevers H. 1998. Depletion of epithelial stemcell compartments in the small intestine of mice lacking Tcf-4. Nat Genet 19: 379-383.

Kosinski C, Li VS, Chan AS, Zhang J, Ho C, Tsui WY, Chan TL, Mifflin RC, Powell DW, Yuen ST, et al. 2007. Gene expression patterns of human colon tops and basal crypts and BMP antagonists as intestinal stem cell niche factors. Proc Natl Acad Sci 104: 15418-15423.

Kuhnert F, Davis CR, Wang HT, Chu P, Lee M, Yuan J, Nusse R, Kuo CJ. 2004. Essential requirement for Wnt signaling in proliferation of adult small intestine and colon revealed by adenoviral expression of Dickkopf-1. Proc Natl Acad Sci 101: 266-271.

Leblond CP, Stevens CE, Bogoroch R. 1948. Histological localization of newly-formed desoxyribonucleic acid. Science 108: 531-533.

Lee ER, Leblond CP. 1985. Dynamic histology of the antral epithelium in the mouse stomach: II. Ultrastructure and renewal of isthmal cells. Am J Anat 172: 205-224.

Leedham SJ, Brittan M, McDonald SA, Wright NA. 2005. Intestinal stem cells. J Cell Mol Med 9: 11-24.

Li Q, Ishikawa TO, Oshima M, Taketo MM. 2005. The threshold level of adenomatous polyposis coli protein for mouse intestinal tumorigenesis. Cancer Res 65: 86228627.

Liu W, Dong X, Mai M, Seelan RS, Taniguchi K, Krishnadath KK, Halling KC, Cunningham JM, Boardman LA, Qian C, et al. 2000. Mutations in AXIN2 cause colorectal cancer with defective mismatch repair by activating $\beta$-catenin/TCF signalling. Nat Genet 26: 146-147.

Luo F, Brooks DG, Ye H, Hamoudi R, Poulogiannis G, Patek CE, Winton DJ, Arends MJ. 2009. Mutated K-ras(Asp12) promotes tumourigenesis in $\mathrm{Apc}(\mathrm{Min})$ mice more in the large than the small intestines, with synergistic effects between K-ras and Wnt pathways. Int J Exp Pathol 90: $558-574$.

Madara JL. 1982. Cup cells: Structure and distribution of a unique class of epithelial cells in guinea pig, rabbit, and monkey small intestine. Gastroenterology 83: 981-994.

Marsh V, Winton DJ, Williams GT, Dubois N, Trumpp A, Sansom OJ, Clarke AR. 2008. Epithelial Pten is dispensable for intestinal homeostasis but suppresses adenoma development and progression after Apc mutation. Nat Genet 40: 1436-1444.

McDonald SA, Greaves LC, Gutierrez-Gonzalez L, Rodriguez-Justo M, Deheragoda M, Leedham SJ, Taylor RW, Lee CY, Preston SL, Lovell M, et al. 2008. Mechanisms of field cancerization in the human stomach: The expansion and spread of mutated gastric stem cells. Gastroenterology 134: $500-510$. 
Montgomery RK, Carlone DL, Richmond CA, Farilla L, Kranendonk ME, Henderson DE, Baffour-Awuah NY, Ambruzs DM, Fogli LK, Algra S, et al. 2011. Mouse telomerase reverse transcriptase (mTert) expression marks slowly cycling intestinal stem cells. Proc Natl Acad Sci 108: 179-184.

Mori-Akiyama Y, van den Born M, van Es JH, Hamilton SR, Adams HP, Zhang J, Clevers H, de Crombrugghe B. 2007. SOX9 is required for the differentiation of paneth cells in the intestinal epithelium. Gastroenterology 133: 539-546.

Morin PJ, Sparks AB, Korinek V, Barker N, Clevers H, Vogelstein B, Kinzler KW. 1997. Activation of $\beta$-catenin-Tcf signaling in colon cancer by mutations in $\beta$-catenin or APC. Science 275: 1787-1790.

Morita H, Mazerbourg S, Bouley DM, Luo CW, Kawamura K, Kuwabara Y, Baribault H, Tian H, Hsueh AJ. 2004. Neonatal lethality of LGR5 null mice is associated with ankyloglossia and gastrointestinal distension. Mol Cell Biol 24: 9736-9743.

Moser AR, Pitot HC, Dove WF. 1990. A dominant mutation that predisposes to multiple intestinal neoplasia in the mouse. Science 247: 322-324.

Mustata RC, Van Loy T, Lefort A, Libert F, Strollo S, Vassart G, Garcia MI. 2011. Lgr4 is required for Paneth cell differentiation and maintenance of intestinal stem cells ex vivo. EMBO Rep 12: 558-564

Nakatsuru S, Yanagisawa A, Ichii S, Tahara E, Kato Y, Nakamura Y, Horii A. 1992. Somatic mutation of the APC gene in gastric cancer: Frequent mutations in very well differentiated adenocarcinoma and signet-ring cell carcinoma. Hum Mol Genet 1: 559-563.

Nishisho I, Nakamura Y, Miyoshi Y, Miki Y, Ando H, Horii A, Koyama K, Utsunomiya J, Baba S, Hedge P. 1991. Mutations of chromosome 5q21 genes in FAP and colorectal cancer patients. Science 253: 665-669.

Nomura S, Esumi H, Job C, Tan SS. 1998. Lineage and clonal development of gastric glands. Dev Biol 204: 124-135.

O'Brien CA, Pollett A, Gallinger S, Dick JE. 2007. A human colon cancer cell capable of initiating tumour growth in immunodeficient mice. Nature 445: 106-110.

Odoux C, Fohrer H, Hoppo T, Guzik L, Stolz DB, Lewis DW, Gollin SM, Gamblin TC, Geller DA, Lagasse E. 2008. A stochastic model for cancer stem cell origin in metastatic colon cancer. Cancer Res 68: 6932-6941.

Offerhaus GJ, Giardiello FM, Krush AJ, Booker SV, Tersmette AC, Kelley NC, Hamilton SR. 1992. The risk of upper gastrointestinal cancer in familial adenomatous polyposis. Gastroenterology 102: 1980-1982.

Oguma K, Oshima H, Aoki M, Uchio R, Naka K, Nakamura S, Hirao A, Saya H, Taketo MM, Oshima M. 2008. Activated macrophages promote Wnt signalling through tumour necrosis factor- $\alpha$ in gastric tumour cells. $E M B O$ 27: $1671-1681$.

Oshima M, Oshima H, Kitagawa K, Kobayashi M, Itakura C, Taketo M. 1995. Loss of Apc heterozygosity and abnormal tissue building in nascent intestinal polyps in mice carrying a truncated Apc gene. Proc Natl Acad Sci 92: $4482-4486$.

Oshima H, Oshima M, Kobayashi M, Tsutsumi M, Taketo MM. 1997. Morphological and molecular processes of polyp formation in $\operatorname{Apc}(\delta 716)$ knockout mice. Cancer Res 57: 1644-1649.
Oshima H, Matsunaga A, Fujimura T, Tsukamoto T, Taketo MM, Oshima M. 2006. Carcinogenesis in mouse stomach by simultaneous activation of the Wnt signaling and prostaglandin E2 pathway. Gastroenterology 131: $1086-$ 1095.

Pan KF, Liu WG, Zhang L, You WC, Lu YY. 2008. Mutations in components of the Wnt signaling pathway in gastric cancer. World J Gastroenterol 14: 1570-1574.

Park WS, Oh RR, Park JY, Lee SH, Shin MS, Kim YS, Kim SY, Lee HK, Kim PJ, Oh ST, et al. 1999. Frequent somatic mutations of the $\beta$-catenin gene in intestinal-type gastric cancer. Cancer Res 59: 4257-4260.

Pinto D, Gregorieff A, Begthel H, Clevers H. 2003. Canonical Wnt signals are essential for homeostasis of the intestinal epithelium. Genes Dev 17: 1709-1713.

Potten CS, Kovacs L, Hamilton E. 1974. Continuous labelling studies on mouse skin and intestine. Cell Tissue Kinet 7: $271-283$

Potten CS, Owen G, Roberts SA. 1990. The temporal and spatial changes in cell proliferation within the irradiated crypts of the murine small intestine. Int J Radiat Biol 57: 185-199.

Qiao XT, Ziel JW, McKimpson W, Madison BB, Todisco A, Merchant JL, Samuelson LC, Gumucio DL. 2007. Prospective identification of a multilineage progenitor in murine stomach epithelium. Gastroenterology 133: 1989-1998.

Reya T, Clevers H. 2005. Wnt signalling in stem cells and cancer. Nature 434: 843-850.

Ricci-Vitiani L, Lombardi DG, Pilozzi E, Biffoni M, Todaro M, Peschle C, De Maria R. 2007. Identification and expansion of human colon-cancer-initiating cells. Nature 445: 111-115.

Rubinfeld B, Albert I, Porfiri E, Fiol C, Munemitsu S, Polakis P. 1996. Binding of GSK3 $\beta$ to the APC- $\beta$-catenin complex and regulation of complex assembly. Science 272: $1023-1026$.

Sabates-Bellver J, Van der Flier LG, de Palo M, Cattaneo E, Maake C, Rehrauer H, Laczko E, Kurowski MA, Bujnicki JM, Menigatti M, et al. 2007. Transcriptome profile of human colorectal adenomas. Mol Cancer Res 5: $1263-$ 1275.

Sangiorgi E, Capecchi MR. 2008. Bmil is expressed in vivo in intestinal stem cells. Nat Genet 40: 915-920.

Sansom OJ, Reed KR, Hayes AJ, Ireland H, Brinkmann H, Newton IP, Batlle E, Simon-Assmann P, Clevers H, Nathke IS, et al. 2004. Loss of Apc in vivo immediately perturbs Wnt signaling, differentiation, and migration. Genes Dev 18: 1385-1390.

Sansom OJ, Meniel VS, Muncan V, Phesse TJ, Wilkins JA, Reed KR, Vass JK, Athineos D, Clevers H, Clarke AR. 2007. Myc deletion rescues Apc deficiency in the small intestine. Nature 446: 676-679.

Sato T, Vries RG, Snippert HJ, van de Wetering M, Barker N, Stange DE, van Es JH, Abo A, Kujala P, Peters PJ, et al. 2009. Single Lgr5 stem cells build crypt-villus structures in vitro without a mesenchymal niche. Nature 459: 262 265.

Sato T, van Es JH, Snippert HJ, Stange DE, Vries RG, van den Born M, Barker N, Shroyer NF, van de Wetering M, Clevers H. 2011. Paneth cells constitute the niche for Lgr5 stem cells in intestinal crypts. Nature 469: 415-418. 
A. Schepers and H. Clevers

Schepers AG, Vries R, van den Born M, van de Wetering M, Clevers H. 2011. Lgr5 intestinal stem cells have high telomerase activity and randomly segregate their chromosomes. EMBO J 30: 1104-1109.

Shih IM, Wang TL, Traverso G, Romans K, Hamilton SR Ben-Sasson S, Kinzler KW, Vogelstein B. 2001. Top-down morphogenesis of colorectal tumors. Proc Natl Acad Sci 98: $2640-2645$.

Snippert HJ, van Es JH, van den Born M, Begthel H, Stange DE, Barker N, Clevers H. 2009. Prominin-1/CD133 marks stem cells and early progenitors in mouse small intestine. Gastroenterology 136: 2187.e1-2194.e1.

Snippert HJ, van der Flier LG, Sato T, van Es JH, van den Born M, Kroon-Veenboer C, Barker N, Klein AM, van Rheenen J, Simons BD, et al. 2010. Intestinal crypt homeostasis results from neutral competition between symmetrically dividing Lgr5 stem cells. Cell 143: 134-144.

Soreide K, Janssen EA, Soiland H, Korner H, Baak JP. 2006. Microsatellite instability in colorectal cancer. BrJ Surg 93: 395-406.

Su LK, Kinzler KW, Vogelstein B, Preisinger AC, Moser AR Luongo C, Gould KA, Dove WF. 1992. Multiple intestinal neoplasia caused by a mutation in the murine homolog of the APC gene. Science 256: 668-670.

Takashima S, Kadowaki M, Aoyama K, Koyama M, Oshima T, Tomizuka K, Akashi K, Teshima T. 2011. The Wnt agonist R-spondin1 regulates systemic graft-versus-host disease by protecting intestinal stem cells. J Exp Med 208: 285-294.

Takeda N, Jain R, LeBoeuf MR, Wang Q, Lu MM, Epstein JA. 2011. Interconversion between intestinal stem cell populations in distinct niches. Science 334: 1420-1424.

Taylor RW, Barron MJ, Borthwick GM, Gospel A, Chinnery PF, Samuels DC, Taylor GA, Plusa SM, Needham SJ, Greaves LC, et al. 2003. Mitochondrial DNA mutations in human colonic crypt stem cells. J Clin Invest 112: $1351-1360$.

Tetsu O, McCormick F. 1999. $\beta$-catenin regulates expression of cyclin D1 in colon carcinoma cells. Nature 398: 422426.

Thompson M, Fleming KA, Evans DJ, Fundele R, Surani MA, Wright NA. 1990. Gastric endocrine cells share a clonal origin with other gut cell lineages. Development 110: $477-481$.

Tian H, Biehs B, Warming S, Leong KG, Rangell L, Klein OD, de Sauvage FJ. 2011. A reserve stem cell population in small intestine renders Lgr5-positive cells dispensable. Nature 478: 255-259.

Tomita H, Yamada Y, Oyama T, Hata K, Hirose Y, Hara A, Kunisada T, Sugiyama Y, Adachi Y, Linhart H, et al. 2007.
Development of gastric tumors in $A p c^{\mathrm{Min} /+}$ mice by the activation of the $\beta$-catenin/Tcf signaling pathway. Cancer Res 67: 4079-4087.

Ushijima T, Sasako M. 2004. Focus on gastric cancer. Cancer Cell 5: 121-125.

van der Flier LG, Sabates-Bellver J, Oving I, Haegebarth A, De Palo M, Anti M, Van Gijn ME, Suijkerbuijk S, van de Wetering M, Marra G, et al. 2007. The intestinal Wnt/ TCF signature. Gastroenterology 132: 628-632.

van der Flier LG, Haegebarth A, Stange DE, van de Wetering M, Clevers H. 2009a. OLFM4 is a robust marker for stem cells in human intestine and marks a subset of colorectal cancer cells. Gastroenterology 137: 15-17.

van der Flier LG, van Gijn ME, Hatzis P, Kujala P, Haegebarth A, Stange DE, Begthel H, van den Born M, Guryev V, Oving I, et al. 2009b. Transcription factor achaete scute-like 2 controls intestinal stem cell fate. Cell 136: 903-912.

van de Wetering M, Sancho E, Verweij C, de Lau W, Oving I, Hurlstone A, van der Horn K, Batlle E, Coudreuse D, Haramis AP, et al. 2002. The $\beta$-catenin/TCF-4 complex imposes a crypt progenitor phenotype on colorectal cancer cells. Cell 111: 241-250.

van Es JH, Jay P, Gregorieff A, van Gijn ME, Jonkheer S, Hatzis $\mathrm{P}$, Thiele A, van den Born M, Begthel H, Brabletz T, et al. 2005. Wnt signalling induces maturation of Paneth cells in intestinal crypts. Nat Cell Biol 7: 381-386.

Vermeulen L, De Sousa EMF, van der Heijden M, Cameron K, de Jong JH, Borovski T, Tuynman JB, Todaro M, Merz C, Rodermond H, et al. 2010. Wnt activity defines colon cancer stem cells and is regulated by the microenvironment. Nat Cell Biol 12: 468-476.

Wang Y, Giel-Moloney M, Rindi G, Leiter AB. 2007. Enteroendocrine precursors differentiate independently of Wnt and form serotonin expressing adenomas in response to active $\beta$-catenin. Proc Natl Acad Sci 104: 11328-11333.

Wicha MS, Liu S, Dontu G. 2006. Cancer stem cells: An old idea-A paradigm shift. Cancer Res 66: 1886-1890.

Winton DJ, Ponder BA. 1990. Stem-cell organization in mouse small intestine. Proc Biol Sci 241: 13-18.

Zeilstra J, Joosten SP, Dokter M, Verwiel E, Spaargaren M, Pals ST. 2008. Deletion of the WNT target and cancer stem cell marker CD44 in $A p c^{\mathrm{Min} /+}$ mice attenuates intestinal tumorigenesis. Cancer Res 68: 3655-3661.

Zhu L, Gibson P, Currle DS, Tong Y, Richardson RJ, Bayazitov IT, Poppleton H, Zakharenko S, Ellison DW, Gilbertson RJ. 2009. Prominin 1 marks intestinal stem cells that are susceptible to neoplastic transformation. Nature 457: 603-607. 


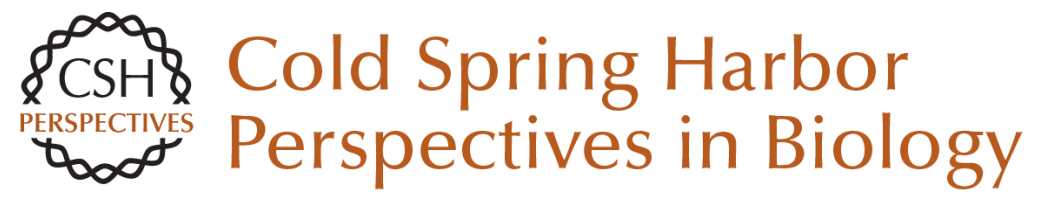

\section{Wnt Signaling, Stem Cells, and Cancer of the Gastrointestinal Tract}

Arnout Schepers and Hans Clevers

Cold Spring Harb Perspect Biol 2012; doi: 10.1101/cshperspect.a007989

Subject Collection Wnt Signaling

Wnt Signaling in Vertebrate Axis Specification Hiroki Hikasa and Sergei Y. Sokol

Secreted and Transmembrane Wnt Inhibitors and Activators Cristina-Maria Cruciat and Christof Niehrs

Wnt Signaling in Normal and Malignant

Hematopoiesis William Lento, Kendra Congdon, Carlijn Voermans, et al.

Frizzled and LRP5/6 Receptors for Wnt/ $/$-Catenin Signaling Bryan T. MacDonald and Xi He

TCF/LEFs and Wnt Signaling in the Nucleus Ken M. Cadigan and Marian L. Waterman

Alternative Wnt Pathways and Receptors Renée van Amerongen

$\beta$-Catenin-Dependent Wnt Signaling in C. elegans:

Teaching an Old Dog a New Trick Belinda M. Jackson and David M. Eisenmann

The Evolution of the Wnt Pathway Thomas W. Holstein
The $\beta$-Catenin Destruction Complex Jennifer L. Stamos and William I. Weis

Wnt Signaling in Skin Development, Homeostasis, and Disease Xinhong Lim and Roel Nusse

Wnt Signaling in Bone Development and Disease:

Making Stronger Bone with Wnts Jean B. Regard, Zhendong Zhong, Bart $O$. Williams, et al.

Targeting Wnt Pathways in Disease Zachary F. Zimmerman, Randall T. Moon and Andy J. Chien

Wnt Signaling in Mammary Glands: Plastic Cell

Fates and Combinatorial Signaling Caroline M. Alexander, Shruti Goel, Saja A. Fakhraldeen, et al.

Wnt Signaling and Injury Repair Jemima L. Whyte, Andrew A. Smith and Jill A. Helms

Wnt Signaling and Forebrain Development Susan J. Harrison-Uy and Samuel J. Pleasure

Wnt Signaling in Neuromuscular Junction Development Kate Koles and Vivian Budnik

For additional articles in this collection, see http://cshperspectives.cshlp.org/cgi/collection/

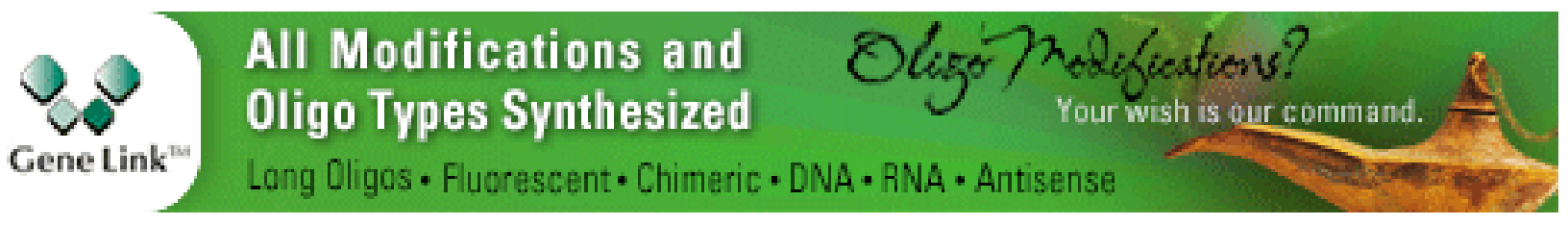

